\title{
CORRIGENDUM \\ RIP1 is required for IAP inhibitor-mediated sensitization of childhood acute leukemia cells to chemotherapy-induced apoptosis
}

S Loeder, M Schirmer, H Schoeneberger, S Cristofanon, J Leibacher, N Vanlangenakker, MJM Bertrand, P Vandenabeele, I Jeremias, K-M Debatin and S Fulda

Leukemia (2012) 26, 1742; doi:10.1038/leu.2012.131

Correction to: Leukemia (2012) 26, 1020-1029; doi:10.1038/ leu.2011.353

Since the publication of this paper, the authors have noticed that two of the author names in the affiliations were incorrectly listed as S Löder and M Fakler.
The correct names are listed above.

The authors would like to apologise for any inconvenience this may have caused. 